\title{
Pentingnya Materi Lingkungan dalam Pembelajaran Bahasa Indonesia di Sekolah
}

\author{
Oleh: Frisca Dilla \\ friscadilla9@gmail.com
}

Menyikapi bahwa daerah-daerah di Indonesia begitu rawan akan bencana alam, kita tentunya harus memahami bagaimana pentingnya mempelajari materi mengenai bencana alam. Seperti yang kita ketahui, akhir-akhir ini banyak terjadi bencana alam di tanah air. Tentunya hal ini harus menjadi perhatian khusus bagi seluruh lapisan masyarakat. Nkwetisma (dalam Ramadhan et al, 2019) menjelaskan bahwa pendidikan lingkungan adalah upaya bersama yang secara sadar diselenggarakan untuk mengajarkan atau menarik perhatian manusia tentang bagaimana fungsi lingkungan alam dan bagaimana manusia ini dapat mengelola dan juga melindunginya. Pemerintah juga sudah mengeluarkan buku prosedur kedaruratan gempa bumi, tanah longsor, tsunami, dan sebagainya. Akan tetapi, sebatas buku saja tidak menjamin semua orang sadar akan pentingnya penganggulangan bencana. Harus ada proses bimbingan melalui tindakan, seperti simulasi bencana.

Lai (dalam Ramadhan et al, 2019) mengatakan bahwa "environmental problems are inherently inseparable from environmental awareness, values, and attitudes of people. This encourages countries to start assessing environmental education [2]." Masalah lingkungan secara langsung tidak dapat dipisahkan dari kesadaran lingkungan, nilai-nilai, dan juga perilaku manusia. Ini mendorong negara harus sudah memulai pendidikan lingkungan. West (dalam Ramadhan et al, 2019) juga berpendapat bahwa pendidikan lingkungan juga menghasilkan keterampilan perilaku dan aturan tertentu dalam kaitannya dengan lingkungan, dan mengembangkan optimalisasi dan harmoni antara manusia dan alam. Di negara maju seperti Jepang, mereka bahkan telah menerapkan pendidikan kebencanaan sejak sekolah. Hal ini juga harus dicontoh oleh negara Indonesia, bahwa pendidiknan tentang mitigasi bencana ini sangat penting untuk diterapkan di sekolah. Belajar dari negara luar, pendidikan, pelatihan dan simulasi perlu menjadi akar utama untuk masyarakat di berbagai daerah, sehingga masyarakat tak hanya cepat tanggap setelah terjadi, tetapi juga lebih siaga dan mampu bertindak sebelum maupun sesudah terjadinya bencana. 
Penulis telah menyebarkan angket mengenai pentingnya materi tentang bencana alam yang ditujukan kepada mahasiswa S1 dari berbagai jurusan dan juga jenis kelamin. Berdasarkan hasil penelitian penulis terhadap sedikitnya 36 orang mahasiswa, sekitar 58,3\% mahasiswa menyatakan kurang setuju bahwa materi mengenai bencana alam akan menghambat proses pembelajaran bahasa Indonesia di sekolah dan selebihnya 36,1\% mahasiswa justru menyatakan tidak setuju bahwa materi mengenai lingkungan menghambat proses pembelajaran bahasa Indonesia. Sebanyak 61,1\% mahasiswa setuju bahwa materi mengenai bencana alam akan menambah kreativitas siswa dalam pembelajaran bahasa Indonesia dan selebihnya sebanyak 33,3\% mahasiswa justru sangat setuju. Materi tentang simulasi bencana alam dapat dijadikan sebagai contoh pembelajaran bahasa Indonesia, sebanyak 69,4\% mahasiswa setuju mengenai hal tersebut, sebanyak 27,8\% mahasiswa sangat setuju akan hal itu. Dengan adanya materi mengenai lingkungan, maka akan menumbuhkan minat dan semangat siswa dalam pembelajaran bahasa Indonesia, sebanyak 77,8\% mahasiswa setuju, 19,4\% sangat setuju. Penerapan materi lingkungan dalam pembelajaran Bahasa Indonesia dapat menambah wawasan peserta didik mengenai bencana alam, sebanyak 69,4\% mahasiswa sangat setuju akan hal tersebut, 25\% mahasiswa setuju. Materi mengenai lingkungan (bencana alam) memberikan dampak positif dalam pembelajaran Bahasa Indonesia, sebanyak 52,8\% setuju, 41,7\% sangat setuju. Pembelajaran mengenai mitigasi bencana dapat me-refreshing otak peserta didik ketika belajar mata pelajaran Bahasa Indonesia, sebanyak 69,4\% mahasiswa menyatakan setuju, $27,8 \%$ menyatakan sangat setuju. Pertanyaan terakhir sebagai penutup, apakah Saudara setuju materi mengenai lingkungan diajarkan dalam pembelajaran Bahasa Indonesia di sekolah? Hasilnya sebanyak 50\% mahasiswa menyatakan setuju, dan sebagiannya lagi justru menyatakan sangat setuju.

Berdasarkan hasil penelitian yang telah penulis lakukan, dapat disimpulkan bahwasannya lebih dari sebagian mahasiswa setuju tentang pentingnya diadakan materi mengenai lingkungan di sekolah. Bahkan, ada yang justru menyatakan sangat setuju akan pentingnya materi mengenai bencana alam. Untuk itu, lembaga pendidikan memiliki peran yang sangat penting dalam proses memberikan pendidikan wawasan mengenai materi bencana alam. Guru mata pelajaran Bahasa Indonesia haruslah memiliki pemahaman ataupun wawasan yang luas mengenai mitigasi bencana. Menurut Fidan N dan Ay T S (dalam Ramadhan et al, 2019), untuk mencapai hal ini, guru harus memiliki minat dalam menggunakan tema yang terkait dengan masalah global mengenai lingkungan, memiliki pemahaman yang berkualitas, dan sikap positif terhadap lingkungan. Dengan demikian, tidak hanya bagi guru saja, tetapi menjadi bahan evaluasi juga bagi kita bersama untuk lebih menjaga lingkungan. 


\section{Daftar Rujukan}

Fidan N and Ay T S 2016 Acquisition of operational environmental literacy in social studies course International Journal of Environmental \& Science Education 11(13) 5951-68.

Lai C S 2018 A study of fifth graders' environmental learning outcomes in Taipei International Journal of Research in Education and Science 4(1) 252-61.

Nkwetisma C M 2011 EFL/ESL and environmental education: towards an eco-applied linguistic awareness in Cameroon World Journal of Education 1(1) 110-18.

Ramadhan, S. Sukma, E. and Indriyani, V. 2019. Environtmental education and disaster mitigation through language learning. IOP Conference Series: Earth and Environmental Science, 314, pp.1-9.

West S E 2015 Understanding participant and practitioner outcomes of environmental education Environmental Education Research 21(1) 45-60. 